\title{
'n Vergelyking van die Invloed van Sekere Kontekstuele Faktore op die Simptome van Persone met Verworwe Verbale Apraksie en Verbale Ontwikkelingsapraksie
}

\author{
A. van der Merwe, D.Phil (Pretoria) \\ Departement Spraakheelkunde en Oudiologie \\ Universiteit van Pretoria \\ R.J. Grimbeek, M.Sc (Pretoria) \\ Departement Statistiek \\ Universiteit van Pretoria
}

\section{OPSOMMING}

Gegewens oor die individuele simptome van persone met verworwe verbale apraksie en verbale ontwikkelingsapraksie is van teoretiese belang vir die studie van verbale apraksie. Deur die vergelyking van individuele simptome kan liggewerp word op simptoombeelde of tipes verbale apraksie en op die aard van die afuyking by verworwe verbale apraksie en verhale ontwikkelingsapraksie. In hierdie ondersoek wat deel uitmaak van die groter ondersoek waarin die effek van variasie in kontekstuele faktore op verbaal apraktiese spraak nagegaan word (Van der Merwe, Uys, Loots en Grimbeek, 1987; 1988; Van der Merwe, Uys, Loots, Grimbeek en Jansen, 1989) is die simptome van vier persone met verworwe verbale apraksie en een persoon met verbale ontwikkelingsapraksie onderling vergelyk. Die ouditief waarneembare foute en afuykings in stemaanvangstyd, vokaalduur en uitingduur van die proefpersone is vergelyk. Die resultate toon onder andere aan dat die frekwensie van voorkoms van sekere simptome a anleiding:gee tot individuele simptoombeelde, maar dat al die proefpersone die hoë voorkoms van simptome wat aanduidend is van die aard van die afwyking:gemeen het. Die proefpersoon met verbale ontwikkelingsapraksie het al die simptome gemeen met die groep, maar vertoon minder afwykings in temporale vloei en uitingduur en meer klankvervangings. Die teoretiese implikasies van die resultate word bespreek.

\section{SUMMARY}

Data on the individual symptoms of patients with acquired apraxia of speech and developmental apraxia of speech is of theoretical significance in the study of this disorder. A comparison of individual symptoms may shed light on error patterns in apraxia of speech, the possibility of types of apraxia of speech and on the nature of the disorder. In this study which was part of the wider investigation into the effect of variation in contextual factor's on apraxia of speech (Van der Merwe, Uys, Loots and Grimbeek, 1987; 1988; Van der Merwe, Uys, Loots, Grimbeek and Jansen, 1989) the symptoms of four patients with acquired apraxia of speech and one subject with developmental apraxia of speech were compared. The auditorily perceived symptoms and the deviations in voice onset time, vowel duration and utterance duration of all the subjects were compared. The results indicated that the frequency of occurrence of certain symptoms created individual error patterns but also that all subjects had the high occurrence of symptoms which reflect the nature of the disorder in common. The subject with developmental apraxia of speech had all symptoms in common with the other subjects but exhibited less deviancy in the temporal flow of speech and in the duration of the utterance. He presented with more sound substitutions than did the acquired group. The theoretical implications of the results are discussed.

Tydens die navorsing oor die invloed van sekere kontekstuele faktore op ouditief waarneembare foute, stemaanvangstyd, vokaalduur en uitingduur by verbale apraksie (Van der Merwe, Uys, Loots \& Grimbeek, 1987; 1988; Van der Merwe, Uys, Loots, Grimbeek en Jansen, 1989) was die analises gebaseer op groepresultate alhoewel aandag ook subjektief geskenk is aan die gedrag van individue bịne die groep. Die data van die individuele proefpersone is egter ook statisties onderling vergelyk en in die huidige artikel word hierdie resultate aangebied. Analise van die individuele resultate was belangrik aangesien dit bekend is dat alle apraktiese persone nie alle simptome gemeen het nie (Wertz, La Pointe \& Rosenbek, 1984) en ook omdat'n proefpersoon met verbale ontwikkelingsapraksie (VOA) by die eksperimentele groep ingesluit was. Gegewens oor die individuele simptome van proefpersone met verworwe verbale apraksie (VVA) en VOA is van teoretiese belang vir die studie van verbale apraksie.
Diagnostiese kriteria gegrond op sekere kenmerkende eienskappe van VVA is vir die eerste keer geformuleer en in navorsing geïmplimenteer deur Kent en Rosenbek (1983). Hulle noem die volgende eienskappe van VVA as kriteria:

- Worstelende en soekende probeer-en-tref artikulasiebewegings en pogings tot selfkorreksie;

- Disprosodie met geen verlengde periodes van normale ritme, klem en intonasie nie;

- Foutonkonstantheid by herhaalde produksies van dieselfde eenheid;

- Opsigtelike probleme in die inisiëring van uitinge.

Dieselfde kriteria (tesame met ander kriteria wat die teenwoordigheid van afasie en disartrie uitskakel) is vir die seleksie van proefpersone in die huidige ondersoek gebruik. Dit was reeds by seleksie duidelik dat nie alle simptome by al die proefpersone voorkom nie. Die moontlikheid van verskillende tipes 
verbale apraksie is reeds van melding gemaak in die literatuur (Rosenbek, Kent \& La Pointe, 1984; Deutsch, 1984). Die huidige ondersoek kan moontlik 'n bydrae mak tot kennis van individuele foutpatrone van persone wat almal as verbaal aprakties gediagnoseer kan word.

In die huidige ondersoek is daar ook vir die eerste keer sover bekend 'n sistematiese vergelyking in navorsing getref tussen die simptome van persone met VVA en 'n kind wat gediagnoseer is as verbaal aprakties. Die blote bestaan van VOA word soms nog betwyfel (Guyette en Diedrich, 1981; Aram, 1984). Die meeste vooraanstaande navorsers erken egter wel dat verbale apraksie by die kind kan voorkom (Wertz, et al., 1984; Yoss \& Darley, 1974). Die belangrikste struikelblok in die beskrywing van sodanige diagnostiese groep is die gebrek aan diagnostiese kriteria wat hoofsaaklik te wyte is aan onvoldoende navorsing en die beperkte siening van verbale apraksie wat hoofsaaklik gegrond is op die simptome van die verworwe vorm. Die verskille tussen individuele kinders met VOA en die gekombineerde voorkorns met ander probleme veral by die meer algemeen breinbeseerde kind, bemoeilik die diagnose en beskrywing van VOA verder.

Jarelange verkenning in die praktyk dui op die bestaan van minstens drie groepe kinders wat as suiwer verbaal-aprakties beskryf kan word (Van der Merwe, 1985). Die eerste is die groep wat nie-verbaal is, maar met goeie reseptiewe taal. Die tweede is 'n groep wat spraakagtige uitings vertoon soos slegs vokaalproduksie en die derde groep kommunikeer wel verbaal, maar is onverstaanbaar. Beide hierdie groepe beskik ook oor goeie reseptiewe taalvermoë. Verdere navorsing word tans onderneem om hierdie groepe te verifieer. Die kind wat in die huidige ondersoek ingesluit is, het by aanvanklike diagnose in Groep 1, die nie-verbale groep geval.

Afgesien van die vraag of daar wel so'n afwyking soos VOA is, bestaan die vraag ook of die kern van die probleem by die kongenitale of verworwe vorms soortgelyk is. Guyette en Diedrich (1981) verwys in hul bespreking na die rasionaal dat dieselfde benadering in behandeling geskik sal wees vir beide VVA en VOA indien die kern van die probleem ooreenstem. Sodanige waarneming is wel plaaslik gedoen. Die T'erapieprogram vir VOA wat daarop gemik is om die beplanning van spraak te fasiliteer en uit te bou is suksesvol bevind by aldrie bogenoemde tipes VOA en ook by gevalle met suiwer VVA (Van der Merwe, 1985). Guyette en Diedrich (1981:41) meld ook in hul oorsig van VOA dat "it is believed that response to treatment is a strong argument in support of a diagnostic category".

Dit is die teoretiese uitgangspunt in hierdie artikel dat beide VVA en VOA afwykings in die vermoë van die brein is om spraak te beplan of te leer beplan (Van der Merwe, 1986). Indien ooreenstemmende simptome wel gevind word by die proefpersone met VVA en die persoon met VOA sal dit nie alleen die aanvanklike diagnose van VOA grootliks bevestig nie, maar dit sal ook 'n sterk aanduiding wees van die ooreenkoms in die onderliggende aard van die probleem. Die beskrywing van die individuele foutpatrone van al die proefpersone sal ook bydra tot 'n beter gedefinieerde beeld van VVA en VOA.

\section{METODE}

DOEL

Die doel van hierdie bepaalde komponent van die ondersoek is orn die individuele verskille in die simptome van die proefpersone met verworwe verbale apraksie verder toe te lig en ookom te bepaal in watter opsigte die proefpersoon met verbale ontwikkelingsapraksie verskil van of ooreenstem met die ander vier persone met verworwe verbale apraksie.

\section{EKSPERIMENTELE ONTWERP}

Die proefpersone, luisteraars, materiaal en prosedure van ondersoek is reeds volledig beskryf in die voorafgaande artikels (Van der Merwe et al., 1987, 1988, 1989) en slegs enkele belangrike aspekte sal hier herhaal word.

Die totale ondersoek het bestaan uit'n perseptuele analise van die invloed van sekere kontekstuele faktore op die ouditief waarneembare foute van persone met verbale apraksie en uit 'n akoestiese analise van die invloed van dieselfde faktore op stemaanvangstyd (SAT), vokaalduur en uitingduur.

Die kontekstuele faktore wat nagegaan is bestaan uit 'n sistematiese variasie in die klankstruktuur (foneemstruktuur) en die artikulasie-eienskappe (motoriese kompleksiteit) van onsineenhede waarin hierdie eienskappe volkome gekontroleerd is. Die kriteria vir samestelling van hierdie materiaal word volledig beskryf in Van der Merwe (1986). Die materiaal bestaan uit agt eenhede in vyf klankstruktuurgroepe en die eenhede in elke klankstruktuurgroep word verdeel in vier artikulasie-eienskapgroepe (Van der Merwe, et al., 1987). Al die proefpersone het hierdie veertig eenhede ses keer agtereenvolgend herhaal na 'n kort oefenperiode warin elke eenheid eers selfstandig geproduseer moes word. Die uitings was dus selfgeïnisieerd en nie direkte nabootsings nie. Die proefpersone het wel die uitings in 'n geskrewe vorm voor hulle gehad ten einde geheueprobleme sover moontlik te beperk.

Tydens die eerste stadium van die ouditiewe analise van die data is ' $n$ lys saamgestel van alle spraakfoute wat voorgekom het by die vyf proefpersone. Selfs al sou net een van die proefpersone'n sekere simptoom vertoon, is dit in die lysopgeneem. Foutkategoriee is verder in samewerking met twee medeluisteraars saamgestel (Van der Merwe, 1987).

\section{PROEFPERSONE}

Vier persone met verworwe verbale apraksie en een persoon met verbale ontwikkelingsapraksie (VOA) is in hierdie ondersoek gebruik. Die volledige gegewens word aangegee in V'an der Merwe et al., (1987).

Die persoon met verbale ontwikkelingsapraksie is aanvanklik slegs op 'n voorlopige grondslag ingesluit by die ondersoek vanweë die beperkte getal persone met 'n "suiwer" verworwe verbale apraksie wat opgespoor kon word. Daar is later in samewerking met die statistikus besluit dat die resultate van hierdie proefpersoon in so 'n mate ooreenkom met die eksperimentele groep se resultate dat dit tesame daarmee verwerk kan word. 'n Afgepaarde kontrolepersoon is ook vir die proefpersoon met VOA geselekteer vir vergelyking van die akoesties geanaliseerde data.

Ten einde te verseker dat die proefpersoon met VOA (proefpersoon 5) wel verbale apraksie vertoon, is die volgende kenmerkende eienskappe as seleksiekriteria gestel.

- $\quad$ 'n Diskrepansie tussen ekspressiewe en reseptie we taal vermoë wat nie meer as ses maande agter sy chronologiese ouderdom is nie het voorgekom tydens die inisiële diagnose. 
- 'n Onvermoë om willekeurige spraakbewegings uit te voer met gevolglike nie-verbaliteit het voorgekom.

Kommunikasie het deur middel van gebare geskied.

Proefpersoon 5 is op die ouderdom van vier as 'n geval met VOA gediagnoseer.en hy het sedert daardie tyd verbale apraksieterapie (Van der Merwe, 1985) ontvang. Ten tyde van die ondersoek het hy reeds goed verstaanbaar gekommunikeer in vyf- tot seswoordsinne. Ten spyte van die goeie vordering tydens die ses jaar van behandeling het hy steeds simptome van verbale apraksie vertoon en veral die lengte van woorde wat gebruik is, was nog beperk.

Vir die vier persone met verworwe verbale apraksie is die kriteria van Kent en Rosenbek (1983) gestel. Hierdie persone het onvlot spraakproduksie met probeer-en-tref artikulasiebewegings, pogings tot selfkorreksie, onkonstantheid in die foute by herhaalde produksie van dieselfde woord en disprosodie vertoon. Hulle moes ook aan verdere kriteria voldoen om die teenwoordigheid van 'n gepaardgaande afasie of disartrie uit te skakel (Van der Merwe it al., 1987).

ANALISE VAN DIE DATA

Ten einde die mate van afwyking van die groepgemiddeld te bepaal, is similariteitsvektore (Steyn, Smit en du Toit, 1984) vir die individuele proefpersone bereken. By die berekening van similariteitsvektore vir SAT, vokaalduur en uitingsduur is die verskil tussen die gemiddelde foutwaardes van elke persoon en die groepgemiddeld bereken èn die totaal van hierdie verskille is sodoende bekom. Kleiner totale dui op kleiner afwykings vanaf die groepgemiddeld. By die berekening van similariteitsvektore vir ouditief waarneembare foute is die verskil tussen die rangnommer (bepaal op grond van frekwensie van voorkoms) van elke tipe fout van die groep en die rangnommer van elke tipe fout van die individu bereken.

\section{RESULTATE}

Mate van AfWyking van die Individuele Proefpersone VANAF GROEPGEMIDDELDES YIR SAT, VOKAALDUUR, UITINGDUUR EN OUDITIEF WAARNEEMBARE FOUTE

In Tabel 1 word die proefpersone gerangskik in volgorde van afwyking vanaf die groepgemiddeldes vir al die aspekte wat ondersoek is. Persone wat eerste geplaas word wyk die meeste af van die groepgemiddeld en die wat laaste (vyfde) geplaas word, wyk die minste af: In die tweede gedeelte van die tabel word die finale rangorde van elke proefpersoon bepaal. Die hoogste totaal toon die kleinste afwyking vanaf die groep en die kleinste totaal die grootste afwyking.

Die plasing van proefpersone by die verskillende aspekte wat ondersoek is, toon aan dat variasie in individuele simptoombeelde voorkom na gelang van die mate waarin 'n besondere aspek aangetas is. Geen een van die proefpersone neem konstant die eerste of laaste of enige ander posisie in nie.

Proefpersone $1 \mathrm{en} 2$ wat in die finale rangorde die naaste aan die groepgemiddeld gepresteer het, vertoon nie konstant die kleinste verskil van die groep nie. Proefpersoon 1 toon byvoorbeeld by vokaalduur die tweede grootste afwyking van die groep en proefpersoon 2 neem ook dieselfde posisie in ten opsigte van SAT en uitingduur.
Tabel 1: Proefpersone gerangskik in volgorde van afwyking vanaf die groepgemiddeldes vir SAT, vokaalduur, uitingduur en ouditief waarneembare foute

\begin{tabular}{|c|c|c|c|c|c|}
\hline \multirow[t]{2}{*}{$\begin{array}{l}\text { Aspek wat } \\
\text { ontleed is }\end{array}$} & \multicolumn{3}{|c|}{$\begin{array}{l}\text { Verskil meeste } \\
\text { van groep }\end{array}$} & \multicolumn{2}{|c|}{$\begin{array}{l}\text { Verskil minste } \\
\text { van groep }\end{array}$} \\
\hline & 1 & 2 & 3 & 4 & 5 \\
\hline SAT & ${ }^{*}$ pp 3 & pp 2 & pp 4 & pp 5 & pp 1 \\
\hline Vokaalduur & pp 4 & pp 1 & pp 5 & pp 3 & pp 2 \\
\hline Uitingduur & pp 5 & pp 2 & $\mathrm{pp}:$ & pp 1 & pp 4 \\
\hline $\begin{array}{l}\text { Ouditief } \\
\text { waarneem- } \\
\text { bare foute }\end{array}$ & pp 5 & & \multicolumn{2}{|c|}{$\begin{array}{l}\text { pp } 1 \\
\text { pp } 3 \\
\text { pp } 4\end{array}$} & pp 2 \\
\hline Proefpersone & & & \multicolumn{3}{|c|}{$\begin{array}{l}\text { Rangorde van proef- } \\
\text { persoon binne die groep }\end{array}$} \\
\hline $\begin{array}{l}1 \\
2 \\
3 \\
4 \\
5\end{array}$ & $\begin{array}{l}5+2 \\
2+5 \\
1+4 \\
3+1 \\
4+3\end{array}$ & $\begin{array}{l}4+3 \\
2+5 \\
3+3 \\
5+3 \\
1+1\end{array}$ & $\begin{array}{l}14 \mathrm{x} \\
14 \\
11 \\
12 \\
9\end{array}$ & \multicolumn{2}{|c|}{$\begin{array}{l}1 \text { - Verskil minste } \\
2 \quad \text { van groep } \\
4 \\
3 \\
5 \text { - Verskil meeste } \\
\quad \text { van groep }\end{array}$} \\
\hline
\end{tabular}

${ }^{*}$ pp $=$ proefpersoon

$x \quad$ Die persoon met die kleinste totaal het die meeste afgewyk van die groep

Proefpersoon 4 wat telkens tydens die vorige besprekings uitgesonder is (Van der Merwe et al., 1987, 1988, 1989), verskil volgens hierdie analise nie sover van die groep as wat verwag is nie. In die finale rangorde word proefpersoon 4 derde geplaas. Die grootste afwyking vertoon hy by vokaalduur terwyl uitingduur die minste van die groepgemiddeld verskil. Segmentele duur was dus in die besonder versteur, maar totale duur van die uiting is dieselfde as die gemiddeld van die groep. Oorgangtye tussen klanke was dus korter.

Proefpersone 2 en 4 vertoon onderskeidelik ten opsigte van SAT die tweede en derde grootste afwyking van die groep omdat hulle weinig SAT-foute gemaak het. Proefpersoon 3 het daarenteen besonder baie SAT-foute en wyk daarom die meeste af van die groepgemiddeld. Proefpersoon 1 presteer die naaste aan die groepgemiddeld.

Die aard van die SAT-foute wat wel voorgekom het was by al die proefpersone dieselfde, naamlik te groot positiewe tellings wat veroorsaak dat stemhebbende klanke as stemloos geperseptueer word. Die SAT-foute is deur al die proefpersone onkonstant gemaak en daar is bevind dat hierdie foute nie konteks-sensitief is nie. Die foute tree dus onverwags en onvoorspelbaar in.

Die aard van afwykings in vokaalduur en uitingduur was dieselfde by al die proefpersone. In vergelyking met die kontrolepersone het al vyf die proefpersone verlengde vokaalduur en uitingduur vertoon. Statistiese analises het ook aangetoon dat vokaalduur en uitingduur konteks-sensitief is en dat duur toeneem namate die kompleksiteit en lengte van die uiting toeneem. 'n Subjektiewe vergelyking van duurafwykings by die verskillende klankstruktuurgroepe (S) van elke proefpersoon toon aan dat al die proefpersone konteks-sensitiwiteit vertoon. (Kyk tabelle 4 en 5 in Van der Merwe et al., 1989). 
Die totale syfers (soos aangegee in Tabel 1) warmee al die proefpersone afwyk van die groep (9 tot 14) verskil minimaal en dit blyk dus dat nie een van die proefpersone radikaal van die groep verskil nie. Die proefpersone vertoon dieselfde tipe simptome, maar individuele variasie in die mate waarin spesifieke aspekte aangetas is, kom voor.

Die finale rangordes in Tabel 1 toon aan dat proefpersoon 5, die persoon met VOA, die meeste verskil van die groep. Dit is egter slegs ten opsigte van uitingduur en die frekwensiepatroon van ouditief waarneembare foute wat proefpersoon 5 die meeste afwyk van die groep.

WatSAT aanbetref word proefpersoon 5 vierde geplaas en vertoon dus net 'n klein afwyking vanaf die groepgemiddeld. Hierdie proefpersoon het ook soos die ander onkonstante SAT-foute gemaak wat nie konteks-sensitief is nie en die vorm aanneem van te groot positiewe tellings.

Ten opsigte van vokaalduur neem proefpersoon 5 die derde posisie in en vertoon ook verlengde vokaalduur soos die persone met VVA. Vokaalduur is ook by proefpersoon 5 kontekssensitief. Die enigste buitengewone resul taat was dat vokaalduur vir S5 wat 'n KVKVKVK-struktuur het, nie soos by die ander proefpersone meer afwykend was as vokaalduur van die ander klankstruktuurgroepe nie. ' $n$ Moontlike verklaring hiervoor is dat proefpersoon 5 geneig was om eenhede in $\mathrm{S} 5$ fonologies te verkort en spraakproduksie is dan aangepas by die korter en meer eenvoudige eenheid.
Proefpersoon 5 het net soos die ander proefpersone kontekssensitiwiteit in uitingduur vertoon. By $\mathrm{S} 3$ wat ' $\mathrm{K}$ KVKVKstruktuur het, het hy die grootste afwyking en die tweede grootste afwyking was by S5. Klankstruktuurgroep 4 wat 'n KVK-struktuur het, vertoon die kleinste afwyking (Kyk tabel 5 in Van der Merwe et al., 1989). Hierdie patroon van kontekssensitiwiteit is dieselde as by die ander proefpersone.

OUDITIFF WAARNEEMBARE FOUTPATRONE VAN DIE INDIVIDUELE PROEFPERSONE

In Tabel 2 word die frekwensie (en persentasie) van voorkoms vandie foutkategorieë by elke proefpersoon aangegee. Uit die gegewens in hierdie tabel blyk dit dat die proefpersone alle foute gemeen het behalwe dat proefpersoon 1 geen foute gevolg deur selfkorreksie getoon het nie en proefpersoon 4 het geen veranderinge van struktuur getoon nie. Die totale aantal foute toon aan dat wisselende hoeveelhede foute voorkom by die individuele proefpersone. Dit verskaf 'n aanduiding van die graad van aantasting.

Ten einde ' $n$ duideliker beeld te kry van individuele foutpatrone is die foutkategorieë gerangskik in dalende volgorde van voorkoms by elke proefpersoon. Hierdie gegewens word aangegee in tabel 3.

Die rangskikking van foutkategorieë toon aan dat of distorsie (C) of afwykings in temporale vloei (D) die hoogste frekwensie

Tabel 2: Die frekwensie (en persentasie) van voorkoms van die foutkategorieë by elke proefpersoon.

\begin{tabular}{|c|c|c|c|c|c|c|c|}
\hline \multirow[b]{2}{*}{ Proefpersone } & \multicolumn{6}{|c|}{ Foutkategorieë } & \multirow[b]{2}{*}{$\begin{array}{l}\text { Totale } \\
\text { Aantal } \\
\text { Foute }\end{array}$} \\
\hline & \begin{tabular}{|c} 
A \\
Vervangings
\end{tabular} & $\begin{array}{c}\text { B } \\
\text { Verandering } \\
\text { van struktuur }\end{array}$ & $\begin{array}{c}\text { C } \\
\text { Distorsie }\end{array}$ & $\begin{array}{l}\text { D } \\
\text { Afwyking in } \\
\text { temporale } \\
\text { vloei }\end{array}$ & $\begin{array}{l}\mathrm{E} \\
\text { Afwykings in } \\
\text { vlotheid }\end{array}$ & $\begin{array}{c}\text { F } \\
\text { Selfkorreksie } \\
\begin{array}{c}\text { Afwykings in } \\
\text { prosodie }\end{array}\end{array}$ & \\
\hline 1 & 7 & $27 \quad(6,2 \%)$ & ${ }^{227}(52,0 \%)$ & $169(38,8 \%)$ & $5(1,2 \%)$ & ${ }^{0} \quad \begin{array}{l}1 \\
(0 \%)\end{array}$ & $\begin{array}{l}436 \\
(100 \%)\end{array}$ \\
\hline 2 & $11(2,8 \%)$ & 58 (14,6\%) & $94(23,6 \%)$ & $168(42,2 \%)$ & $8(2,0 \%)$ & ${ }^{3}(0,8 \%) \quad 56(14,0 \%)$ & ${ }^{398}(100 \%)$ \\
\hline 3 & $53(8,5 \%)$ & $74 \quad(11,9 \%)$ & $209(33,5 \%)$ & $158(25,3 \%)$ & $87 \quad(14,0 \%)$ & ${ }^{14}(2,2 \%) \quad 29(4,6 \%)$ & $\begin{array}{l}624 \\
(100 \%)\end{array}$ \\
\hline 4 & $25(4,0 \%)$ & $(0 \%)$ & ${ }^{57}(9,2 \%)$ & $\begin{array}{r}359 \\
(58,0 \%)\end{array}$ & $15(2,4 \%)$ & $12(1,9 \%) \quad 152(24,5 \%)$ & $\begin{array}{r}620 \\
(100 \%)\end{array}$ \\
\hline 5 & $118(27,4 \%)$ & $82(19,1 \%)$ & $182(42,4 \%)$ & ${ }^{38}(8,8 \%)$ & $3(0,7 \%)$ & ${ }^{3}(0,7 \%) \quad 4 \quad(0,9 \%)$ & $\begin{array}{l}430 \\
(100 \%)\end{array}$ \\
\hline Totaal & 214 & 241 & 769 & 892 & 118 & 242 & 2508 \\
\hline
\end{tabular}

Tabel 3: Rangskikking van foutkategorieë in dalende volgorde van voorkoms by elke proefpersoon

\begin{tabular}{|c|ccccccc|}
\hline Proefpersone & \multicolumn{7}{|c|}{ Rangskikking van foutkategorieë } \\
\hline 1 & $\mathrm{C}(52,0 \%)$ & $\mathrm{D}(38,8 \%)$ & $\mathrm{B}(6,2 \%)$ & $\mathrm{A}(1,6 \%)$ & $\mathrm{E}(1,2 \%)$ & $\mathrm{G}(0,2 \%)$ & $\mathrm{F}(0,0 \%)$ \\
\hline 2 & $\mathrm{D}(42,2 \%)$ & $\mathrm{C}(23,6 \%)$ & $\mathrm{B}(14,6 \%)$ & $\mathrm{G}(14,0 \%)$ & $\mathrm{A}(2,8 \%)$ & $\mathrm{E}(2,0 \%)$ & $\mathrm{F}(0,8 \%)$ \\
\hline 3 & $\mathrm{C}(33,5 \%)$ & $\mathrm{D}(25,3 \%)$ & $\mathrm{F}(14,0 \%)$ & $\mathrm{B}(11,9 \%)$ & $\mathrm{A}(8,5 \%)$ & $\mathrm{G}(4,6 \%)$ & $\mathrm{F}(2,2 \%)$ \\
\hline 4 & $\mathrm{D}(58,0 \%)$ & $\mathrm{G}(24,5 \%)$ & $\mathrm{C}(9,2 \%)$ & $\mathrm{A}(4,0 \%)$ & $\mathrm{E}(2,4 \%)$ & $\mathrm{F}(1,9 \%)$ & $\mathrm{B}(\mathrm{0} \%)$ \\
\hline 5 & $\mathrm{C}(42,4 \%)$ & $\mathrm{A}(27,4 \%)$ & $\mathrm{B}(19,1 \%)$ & $\mathrm{D}(8,8 \%)$ & $\mathrm{G}(0,9 \%)$ & $\mathrm{F}(0,7 \%)$ & $\mathrm{F}(0,7 \%)$ \\
\hline
\end{tabular}


van voorkoms vertoon by al die proefpersone. By drie van die proefpersone neem een van hierdie foute ook die tweede plek in. Dit is slegs proefpersone 4 en 5 wat nie hierdie patroon volg nie. By proefpersoon 4 neem distorsie wel die derde plek in.

Afwykings in vlotheid (E), foute gevolg deur selfkorreksie (F) en/of afwykings in prosodie $(G)$ neem by al die proefpersone die voorlaaste en/of die laaste posisie in. Slegs by proefpersoon 4 neem veranderinge in struktuur (B) die laaste posisie in. $\mathrm{Al}$ die proefpersone vertoon dus ook ten opsigte van die laagste voorkoms van spesifieke foutkategorieë ooreenstemmende foutpatrone.

Foutkategorieë A, B en E neem by die meeste proefpersone die middelposisies in. Dit is egter slegs by proefpersoon 3 dat afwykings in vlotheid (E) die derde hoogste frekwensie van voorkoms vertoon. Proefpersoon 3 se spraak was baie meer onvlot en worstelend as die spraak van die ander proefpersone.

Proefpersoon 4 vertoon ook ' $n$ individuele foutpatroon wat hom onderskei van die ander proefpersone. Vanweë die besondere aantasting van proefpersoon 4 neem afwykings in temporale vloei (D) en waarskynlik as gevolg daarvan afwykings in prosodie ( $G$ ) onderskeidelik die eerste en tweede plekke in. Hy is dus die enigste persoon by wie distorsie nie een van die eerste twee plekke inneem nie. Uit die gegèwens in Tabel 2 word dit duidelik dat hierdie persoon baie meer foute in bogenoemde twee aspekte het ( 359 by $D$ en 152 by $G$ ) as die ander proefpersone. Hy was ook die enigste persoon wat nie veranderinge in struktuur (B) vertoon het nie en hy het ook weinig SAT-foute gemaak. Proefpersoon 4 het wel die laagste voorkoms van distorsie-foute, maar die foute wat wel voorgekom het was ook onkonstante distorsies soos teenwoordig by die ander proefpersone.

Die bepaling van similariteitsvektore op grond van foutfrekwensiepatrone (Bylae C) en die rangskikking van proefpersone in volgorde van afwyking van die groep (Tabel 1) toon aan dat proefpersoon 2 die minste verskil van die groep terwyl proefpersone 1, 3 en 4 gesamentlik die middelposisie inneem. Die mate waarin hierdie drie' afwyk van die groep stem dus ooreeń. Die resultate ten opsigte van die ouditief waarneembare foute bevestig dus die resultate van die akoestiese ontledings naamlik dat al die proefpersone die meeste van die foute gemeen het maar dat individuele foutpatrone of simptoombeelde voorkom na gelang van die mate waarin ' $n$ besondere aspek aangetas is. By al die proefpersone vertoon af wy kings in temporale vloei of distorsie die hoogste voorkoms. Al die proefpersone het dus hierdie kenmerk gemeen.

Die rangskikking van proefpersońe in volgorde van afwyking vanafidie groepgemiddeldes in Tabel 1 , toon verder ook aan dat proefpersoon 5 die meeste verskil van die groep ten opsigte van die frekwensiepatroon van ouditief waarneembare foute. Die verrassendste verskynsel is egter dat hierdie proefpersoon met VOA wel dieselfde simptome gemeen het met die ander proefpersone. Die gegewens in Tabel 2 toon aan dat hy foute in elke foutkategorie vertoon het. Geen ander spraakfoute kom by hom voor nie omdat alle foute van al die proefpersone tydens die analise van die data aangeteken is.

Die rangskikking van foutkategorieë in Tabel 3 toon aan dat proefpersoon 5 ook soos twee ander proefpersone die hoogste voorkoms van distorsiefoute vertoon. Die drie simptome (G, E en F) met die laagste voorkoms het hy ook gemeen met die ander proefpersone. Die enigste groot verskille in frekwensie van voorkoms van ouditief waarneembare foute is die hoë voorkoms van vervangingsfoute (A) en die relatief lae voorkoms van afwykings in temporale vloei. Uit Tabel 2 blyk dit dat proefpersoon 5,118 vervangings vertoon het in vergelyking met die ander proefpersone wat gewissel het van 7 tot 53 . Hy vertoon ook meer veranderinge in die struktuur van die eenheid. Dit is moontlik dat hierdie twee probleme saamhang want tydens die ondersoek het dit duidelik geword dat proefpersoon 5 nie die struktuur van S5-eenhede kon onthou of produseer nie. Hy was geneig om hierdie eenhede fonologies te vereenvoudig en/of te verkort. Die lae voorkoms van afwykings in die temporale vloei van spraak by proefpersoon 5 is in ooreenstemming met die akoestiese bepaling van uitingduur. Proefpersoon 5 vertoon minder afwykend as die persone met VVA ten opsigte van beide hierdie aspekte.

Die Invloed van KlankstruktuUr of die Getal Ouditief WAARNeEmbare Foute Yan DIE INDIVIDUELE ProefPERSONe

Die totale aantal ouditiefiwaarneembare foute van al die proef persone by die verskillende klankstruktuurgroepe word aangegee in Tabel 4. In hakies word die rangorde van elke klankstruktuur aangedui. Dit blyk duidelik dat variasie in die aantal foute by die verskillende klankstruktuurgroepe voorkom. Die laagste voorkoms van foute by al die proefpersone is by S4 wat 'n KVK-struktuur het. Die lae voorkoms van foute is deels te wyte aan die korter struktuur wat minder foute toelaat, maar die akoestiese analises van byvoorbeeld die eerste vokaal van al die klankstrukture het aangetoon dat dit nie die oorwegende faktor is nie. Die konteks van die KVK-struktuur het 'n ooreenstemmende invloed gehad op al die proefpersone. Dit is interessant dat dit ook die geval was by proefpersoon 5 want tydens die fasilitasie van verbaliteit by hierdie geval met VOA, het hy die produksie van KVK-strukture eers'n paar jaar na die produksie van KVKV -strukture bemeester.

Tabel 4: Totale getal ouditief waarneembare foute van die vyf proefpersone by die verskillende klankstruktuurgroepe

\begin{tabular}{|l|rrrrr|}
\hline \multirow{2}{*}{$\begin{array}{c}\text { Klank- } \\
\text { struktuur }\end{array}$} & \multicolumn{5}{|c|}{ Proefpersone } \\
\hline 1 & $95(3)$ & $98(5)$ & $132(3)$ & $124(2)$ & $75(3)$ \\
2 & $65(2)$ & $84(2)$ & $109(2)$ & $145(4)$ & $66(2)$ \\
3 & $119(5)$ & $88(3)$ & $151(4)$ & $154(5)$ & $92(4)$ \\
4 & $52(1)$ & $35(1)$ & $76(1)$ & $61(1)$ & $37(1)$ \\
5 & $105(4)$ & $93(4)$ & $156(5)$ & $136(3)$ & $160(5)$ \\
\hline Totale aantal & \multicolumn{7}{|c}{} \\
foute & 436 & 398 & 624 & 620 & 430 \\
\hline
\end{tabular}

Dit blyk verder uit Tabel 4 dat S3 of S5 tot die meeste foute aanleiding gegee het by al die proefpersone behalwe proefpersoon 2. By hierdie persoon het S5 wel die tweede hoogste voorkoms van foute vertoon. Die redes vir die hoër getal foute by hierdie klankstrukture is vroeër reeds volledig bespreek (Van der Merwe et al., 1987, 1988). Binne die konteks van die huidige bespreking is die belangrike punt dat die proefpersone, ingeslote proefpersoon 5 , oorwegend ooreenstemmend gereageer het op variasie in die klankstruktuur van die uiting. Dit is interessant dat ook by proefpersoon $5, \mathrm{~S} 3$ wat slegs een klank langer is as S1 en S2 (KVKVK teenoor KVKV) soveel meer foute tot gevolg het. Dit wil dus voorkom asof die toename in kompleksiteit van die uiting meer probleme in die beplanning van spraak te weeg bring by die proefpersone met VVA maar ook by die proefpersoon met VOA. 


\section{BESPREKING}

Simptoombeelde van Persone met Verworwe Verbale APRAKSIE

Die akoestiese-analise van SAT, vokaalduur en uitingduur en die analise van ouditief waarneembare foute toon aan dat die proefpersone met VVA die meeste van die groepe foute gemeen het, maar dat individuele simptoombeelde na vore kom na gelang van die variërende mate waarin verskillende aspekte aangetas is. Die kollektiewe voorkoms van sekere simptome lei dus tot die beeld van VAA, maar die besondere konstellasie van die simptome verskil skynbaar van persoon tot persoon.

Die analises het egter ook aangetoon dat beide klankdistorsie en afwykings in temporale vloei of een van hierdie twee groepe ouditief waarneembare simptome die hoogste frekwensie van voorkoms by al die proefpersone vertoon het. Die hoë voorkoms van klankdistorsie by al die proefpersone bevestig die uitspraak van Itoh en Sasanuma (1984) dat klankdistorsie waarskynlik die kernsimptoom van verbale apraksie is. Vroeër is distorsie nie gereken as 'n simptoom van verbale apraksie nie. Dit is egter duidelik dat afwykings in die beplanning van spraak onder andere aanleiding kan gee tot onkonstante temporale en ruimtelike oorskreiding van die ekwivalensiegrense van spraakbewegings wat dan aanleiding gee tot klankdistorsie. Die hoë voorkoms van afwykings in temporale vloei is ook in ooreenstemming met die aanvaarde aard van verbale apraksie. Vloei van spraak word belemmer en simptome soos die afbakening van lettergrepe, stadige doelbewuste artikulasie en verlenging van klanke kom voor.

Die hoër frekwensie van voorkoms van sekere simptome by spesifieke persone gee aanleiding tot eiesoortige foutpatrone of simptoombeelde wat moontlik aanduidings is vanverskillende tipes VVA. In die huidige ondersoek het minstens drie verskillende simptoombeelde by die persone met VVA na voregekom. Proefpersoon 3 het groter afwykings in vlotheid as die ander proefpersone vertoon weens worstelende artikulasie. Dit het voorgekom asof die inisiëring van uitings vir haar besonder moeilik was. Proefpersonn 4 daarenteen vertoon 'n hoë voorkoms van verlenging van die statiese periodes van artikulasie met baie min afwykings in vlotheid. Dit het byna voorgekom asof sy spraakafwyking nader aan 'n disartrieseprobleem is as die van die ander proefpersone. Die konstante distorsie en ander uiterlike tekens kenmerkend van disartrie was egter nie teenwoordig nie en die artikulasieverlenging was ook nie konstant teen woordig nie. Die subkortikale skade van hierdie persoon het moontlik aanleiding tot die besondere simptoombeeld gegee. Kertesz (1984) het verbale apraksie by persone met subkortikale skade nagegaan en hy kom tot die slotsom dat die sogenaamde subkortikale sindroom grootliks ooreenkom met die kortikale sindroom. Hy het by die subkortikale sindroom ook disartiese simptome gevind, maar het nie die konstantheid van die simptome nagegaan nie. Proefpersoon 4 het egter kortikale en subkortikale skade gehad.

Proefpersoon 1 vertoon in teenstelling met bogenoemde twee persone die klassieke beeld van suiwer VVA (Itoh \& Sasanuma, 1984; Wertz et al, 1984). Proefpersoon 1 presenteer met die hoogste voorkoms van klankdistorsie en ook'n hoë voorkoms van afwykings in temporale vloei terwyl sy 'n baie lae voorkoms en in baie gevalle die laagste voorkoms van die ander groepe ouditief waarneembare foute vertoon. Die hoë voorkoms van klankdistorsie en afwykings in temporale vloei by hierdie besondere proefpersoon asook die feit dat een of beide van hierdie foute die hoogste voorkoms by al die ander proefpersone vertoon, is 'n sterk aanduiding dat hierdie groepe simptome die kenmerkende eienskappe van VVA is en ook in aanmerking geneem moet word wanneer diagnostiese kriteria vir VVA geformuleer word. Navorsing met groter groepe is egter nodig om hierdie resultate te bevestig.

\section{VERBALE ONTWIKKELINGSAPRAKSIE AS DIAGNOSTIESE ENTITEIT}

Proefpersoon 5 wat op die ouderdom van vier jaar gediagnoseer is as 'n geval met VOA en wat reeds tien jaar oud was ten tyde van die ondersoek, vertoon in die geheel gesien verrasende ooreenstemming met die proefpersone met VVA. Die similariteitsvektore toon aan dat hy wat die totale ondersoek betref die meeste van die groep verskil, maar wat die onderskeie aspekte betref verskil hy slegs ten opsigte van uitingduur en die frekwensiepatroon van ouditief waarneembare foute die meeste van die groep. Hy het egter al die simptome gemeen met die groep.

Proefpersoon 5 vertoon soos die persone met VVA onkonstante SAT-foute wat ook die vorm aanneem van te groot positiewe tellings, verlengde vokaalduur en verlengde uitingduur alhoewel laasgenoemde minder afwykend is as die uitingduur van die persone met WVA. Hy reageer ook dieselfde as die ander, proefpersone op variasie in die klankstruktuur van die uiting. Wat die ouditief waarneembare foute betref het hy die groepe simptome met die hoogste en laagste voorkoms gemeen met die groep. Die distorsiefoute wat by hom soos by twee ander proefpersone die hoogste voorkoms vertoon het, neem ook die vorm aan van onkonstante distorsies van klanke tydens herhaalde produksie van 'n uiting.

Die grootste verskille van die groep vertoon proefpersoon 5 ten opsigte van die hoë voorkoms van klankkvervangings en die lae voorkoms van afwykings in temporale vloei. Die grootste aantal klankvervangings was weens fonologiese vereenvoudiging van die langer eenhede (S5) wat moontlik verband hou met beperkte fonologiese geheue of 'n onvermoë om die lang uitinge te produseer. Die feit dat dit onsineenhede was wat geproduseer moes word, speel waarskynlik ook 'n rol. Dit is ook moontlik dat hierdie simptoom in samehang is met die totale beeld van vertraagde spraakontwikkeling.

Die lae voorkoms van afwykings in temporale vloei wórd bevestig deur die uitingduurmetings. Ten opsigte van uitingduur vertoon proefpersoon 5 die grootste afwyking vanaf die groepgemiddeld omdat sy spraakspoed hoër is. 'n Moontlike verklaring vir hierdie verskynsel is dat alle spraak wat hy wel het doelbewus aangeleer is deur middel van die Terapieprogram vir Verbale Ontwikkelingsapraksie (Van der Merwe, 1985). 'n Belangrike grondbeginsel van die program is dat spraakuitinge doelbewus herhaaldelik geproduseer word sodat outomatisasie kan intree. Alhoewel die proefpersone met VVA dieselfde tipe behandeling ontvang het, is dit moontlik dat doelbewuste beplanning en inisiëring van spraak in groter mate by hulle teen woordig is en meer tyd in beslag neem. Die afleiding kan nie sonder meer gemaak word dat alle kinders met VOA vinniger spraakspoed as persone met VVA vertoon nie omdat die spraak wat proefpersoon 5 het, die resultaat is van hierdie besondere benadering in behandeling.

Die ooreenkoms in simptome van die persoon mét VOA en die ander proefpersone met VVA bevestig nie alleen grootliks die bestaan van VOA as 'n diagnostiese entiteit nie, maar ook die akkuraatheid van die aanvanklike diagnose van VOA. By 
proefpersoon 5 as vierjarige kind het die teenwoordigheid van 'n probleem in die aanleer van die beplanning van spraak daartoe gelei dat hy nie-verbaal was ten spyte van goeie taalbegrip. Dit wil dus voorkom asof die diagnostiese kriteria van Groep 1 VOA (Van der Merwe, 1985) as korrek aanvaar kan word. In die literatuur word geen oorweging daaraan geskenk of die moon tlikheid genoem dat VOA kan presenteer as nie-verbaliteit nie. Die diagnostiese kenmerke wat beskryf word sentreer om die aard van artikulasiefoute en orale apraksie (MacalusoHayes, 1978; Aram, 1984; Yoss \& Darley, 1974) en geeneen van hierdie beskrywings het nog bygedra tot 'n oplossing van die problematiek van die diagnose van VOA nie.

Op grond van die resultate van die huidige ondersoek kan die volgende diagnostiese kriteria van VOA by die kind wat wel verbaliteit verkry het, voorgestel word:

- 'n diskrepansie tussen reseptiewe taalvermoë en ekspressiewe vermoë soos onder andere weerspieël in die lengte van woorde wat geproduseer kan word;

- onkonstante distorsie van konsonante en vokale;

- worsteling by of 'n onvermoë in die produksie van uitinge wat vir die kind moeilik is om te produseer;

- die onvermoë tot lang uitinge lei tot fonologiese verkorting.

Verdere navorsing met groot groepe kinders met VOA moet egter eers uitgevoer word voor hierdie kriteria as korrek aanvaar kan word. Die resultate van die huidige ondersoek laat egter min twyfel oor die bestaan van VOA as 'n diagnostiese entiteit.

Die ooreenstemmende simptome van die proefpersone asook die feit dat proefpersoon 5 op dieselfde wyse as die persone met VVA gereageer het op die variasie in kontekstuele faktore is verder ook sterk aanduidings dat die onderliggende aard van verbale apraksie in die kongenitale en verworwe vorms in belangrike opsigte ooreenkom. In die literatuur word 'n beperkte siening van die aard van verbale apraksie gehandhaaf soos weerspieël in die definiëring van die afwyking. Die algemeen aanvaarde definisie van Darley, Aronson \& Brown (1975: 255) beskryf verbale apraksie as:

"an articulatory disorder resulting from impairment, due to brain damage, of the capacity to program the positioning of speech musculature for the volitional production of phonemes and the sequencing of muscle movements for the production of words."

Hierdie beskrywing is waarskynlik volkome korrek en kan aanvaar word, maar die totale omvang van die motoriese beplanning van spraak en moontlike afwykings daarin word nie in die definisie weerspieël nie. Die beplanning van spraak kan meer omvattend beskryf word as:

- Die herroeping van die onveranderlike kernmotorplan met ruimtelike en temporale spesifikasies van bewegings vir elke foneem,

- die daaropvolgende aanpassing van die kernmotorplan by die klankomgewing, koartikulasiemoontlikhede en die spoed van produksie binne die grense van motoriese ekwivalensie,

- die temporale organisasie van struktuurbewegings en

- die sistematiese vooruitvoering in volgorde van onveranderlike fonologiese eenhede met gespesifiseerde motorplan-subroetines,
- binne die invloed van kontekstuele faktore soos die lengte, klankstruktuur, bekendheid en motoriese kompleksiteit van 'n uiting (Van der Merwe, 1986).

Binne sodanige teoretiese raamwerk kan VVA gesien word as 'n afwyking in een of meer van hierdie stadiums of komponente en VOA as 'n onvermoë om een of meer van hierdie stadiums of komponente te realiseer. Die nie-verbale apraktiese kind leer moontlik nie kernmotorplanne vir klanke aan nie of kan die kern nie aanpas by die klankomgewing nie of kan die agtereenvolgende beplanning en produksie van klanke in 'n woord nie behartig nie. Sodanige teoretiese raamwerk is vanselfsprekend slegs hipoteties, maar dit is duidelik dat logiese verklarings vir die voorkoms van 'n kongenitale en verworwe vorm van verbale apraksie daarop gebaseer kan word. Indringende gevallestudies van groot groepe kinders met VOA sal in die toekoms meer lig werp op die diagnostiese kenmerke en die aard van die probleem by suiwer VOA.

\section{KERNSIMPTOME EN GEASSOSIEERDE SIMPTOME}

In die vorige artikels (Van der Merwe, et al., 1987; 1988; Van der Merwe et al., 1989) is kern- en geassosieerde simptome geidentifiseer op grond van konteks-sensitiwiteit. Daar is gevind dat die ouditief waarneembare simptome met die hoogste voorkoms by al die proefpersone, naamlik klankdistorsie en afwykings in temporale vloei en ook SAT-foute wat dui op temporale interartikulator wankoördinasie nie gereageer het op variasie in konteks nie en dus nie konteks-sensitief was nie Daarteenoor is gevind dat simptome soos klankvervangings, veranderinge in die strukturur van die eenheid deur weglatings en byvoegings van klanke en afwykings in vokaal- en uitingduur toeneem met ' $n$ toename in die lengte of motoriese kompleksiteit van 'n uiting. Hierdie simptome is dus konteks-sensitief en die afleiding is gemaak dat hierdie geassosieerde simptome moontlik kompensatoriese strategieë weerspieël terwyl die simptome wat nie konteks-sensitief is nie en deurentyd in dieselfde mate voorkom waarskynlik aanduidings is van die kern van die probleem en kernsimptome genoem kan word.

Die huidige ondersoek se resultate toon aan dat al die proefpersone, ingeslote proefpersoon 5 , oorwegend ooreenstemmend reageer op die variasie in konteks. Die kernsimptome en geassosieerde simptome stem dus by almal ooreen. Indien die afleiding oor die verdeling van simptome as geldig aanvaar word en die feit dat al die proefpersone oorwegend ooreenstemmende patrone van konteks-sensitiwiteit vertoon bevestig grootliks so 'n afleiding, dan is die implikasie dat die kernsimptome en geassosieerde simptome by VOA en VVA ooreenstem. Die aard van die kernsimptome versterk verder ook die uitgangspunt dat verbale apraksie ' $n$ afwyking in die beplanning van spraak is.

\section{GEVOLGTREKKING}

- Die kollektiewe voorkoms van sekere simptome lei tot die beeld van VVA, maar die besondere konstellasie van simptome op grond van frekwensie van voorkoms verskil van persoon tot persoon.

- Klankdistorsie en/of afwykings in temporale vloei van spraak wat aanduidings is van die kern van die probleem by verbale apraksie vertoon die hoogste frekwensie van voorkoms by al die proefpersone.

- Die frekwensie van voorkoms van sekere simptome gee aanleiding tot individuele simptoombeelde en hierdie simptoombeelde dui op die moontlikheid van tipes verbale apraksie. 
- Die proefpersoon met VOA (proefpersoon 5) verskil in totaal die meeste van die groep, maar wat die onderskeie aspekte betref verskil hy slegs ten opsigte van uitingduur en die frekwensiepatroon van ouditief waarneembare foute die meeste van die groep.

- Proefpersoon 5 het al die simptome gemeen met die groep en die aard van die foute kom ook ooreen, maar die frekwensie van voorkoms van sekere simptome gee aanleiding tot ' $\mathrm{n}$ individuele simptoombeeld.

- Proefpersoon 5 is in teenstelling met die proefpersone met VVA meer geneig om die lang onsineenhede (S5) fonologies te vereenvoudig en vertoon daarom meer klankvervangings. Hierdie verskil kan in samehang met die totale beeld van vertraagde spraakontwikkeling wees.

- Hierdie besondere persoon met VOA vertoon minder probleme met die temporale vloei van spraak en kleiner afwykings in uitingduur as die persone met VVA en dit wil voorkom asof die spraak waaroor hy wel beskik makliker vooraf beplan word as wat die geval is by die persone met VVA.

- Hierdie ondersoek ondersteun die konsep van VOA as 'n diagnostiese entiteit en bevestig ook die diagnose van VOA op grond van nie-verbaliteit by die kind met geen ander bekende/opsigtelike probleme nie.

- Die onderliggende aard van die probleem by VOA en VVA kom in belangrike opsigte ooreen en beide kan waarskynlik as vorms van afwyking in die beplanning van spraak beskou word.

- Konteks-sensitiewe simptome en simptome wat nie konteks-sensitief is nie kom ooreen by al die proefpersone, ingeslote die persoon met VOA. Dit wil dus voorkoms as of kernsimptome en geassosieerde simptome by VOA en VVA ooreenkom.

\section{ERKENNINGS}

Finansiële bystand van die Raad vir Geesteswetenskaplike Navorsing vir hierdie ondersoek, word hiermee erken.

\section{VERWYSINGS}

Aram, D.M. Assessment and treatment of developmental apraxia: Preface. Seminars in Speech and Language, 5, 1984.

Darley, F.L., Aronson, A. F. en Brown, J. Motor Speech Disorders. Philadelphia: Saunders, 1975.
Deutsch, S.F. Prediction of site of lesion from speech apraxia error pat terns. In J.C. Rosenbek, M.R. McNeil en A.E. Aronson (Reds.) Apraxia of Speech: Physiology, Acoustics, Linguistics, Manage ment. Califomia: College-Hill Press, 1984.

Guyette, T.W. en Diedrich, W.M. A critical review of developmental apraxia of speech. In N.J. Lass (Red.). Speech and Language, 5, 1$49,1981$.

Itoh, M. en Sasanuma, S. Articulatory movements in apraxia of speech. In J.C. Rosenbek, M.R. McNeil en A.E. Aronson (Reds.). Apraxia of Speech: Physiology, Acoustics, Linguistics, Management. California: College-Hill Press, 1984.

Kent, R.D. en Rosenbek, J.C. Acoustic patterns of apraxia of speech. Journal of Speech and Hearing Research, 26, 231-249, 1983.

Kertesz, A. Subcortical lesions and verbal apraxia. In J.C. Rosenbek, M.R. McNeil en A.E. Aronson (Reds.). Apraxia of Speech: Phy siology, Acoustics, Linguistics, Management. California: CollegeHill Press, 1984

Macaluso-Haynes, S. Developmental apraxia of speech: Symptoms and treatment. In D.F. Johns (Red.) Clinical Management of Neurogenic Communicative Disorders. Boston: Little, Brown and Company, 1978

Rosenbek, J.C., Kent, R.D. en La Pointe, L.L. Aparxia of speech: An overview of some perspectives. In J.C. Rosenbek, M.R. McNeil and A.E. Aronson (Reds.). Apraxia of Speech: Physiology, Acous tics, Linguistics, Management. California: College-Hill Press, 1984.

Steyn, A.G.W., Smit, G.F. en du Toit, S.H.C. Moderne Statistiek vir die Praktyk. Pretoria: J.L. van Schaik, 1984.

Van der Merwe, A. Terapieprogram vir Verbale Ontwikkelingsapraksie met moontlikhede vir Ander Spraakafuykings. Publikasie van die Universiteit van Pretoria, Pretoria: V\&R, 1985.

Van der Merwe, A. Die Motoriese Beplanning van Spraak by Verbale apraksie. Ongepubliseerde D.Phil-verhandeling. Universiteit van Pretoria, 1986.

Van der Merwe, A., Uys, I.C., Loots, J.M, en Grimbeeck, R.J. Die invloed van sekere kontekstuele faktore op die ouditief warneembare foute by verbale apraksie. Die Suid-Afrikaanse Tydskrif vir Kommunikasieafwykings, 34, 10-22, 1987.

Van der Merwe, A., Uys, I.C., Loots, J.M. en Grimbeek, R.J. Ouditief waarneembare foute by verbale apraksie: Aanduidings van die aard van die afwyking. Die Suid-Afrikaanse Tydskrif vir Kommunikasieafuykings, 35, 45-54, 1988.

Van der Mewre, A., Uys, I.C., Loots, J.M., Grimbeek, R.J. en Jansen, L.P.C. Die invloed van sekere kontekstuele faktore op stemaanvangstyd, vokaalduur en uitingduur by verbale apraksie. Die Suid-Afrikaanse Tydskrif vir Kommunikasieafurykings, 36, 29 $41,1989$.

Wertz, R.T., La Pointe, L.L. en Rosenbek, J.C. Apraxia of Speech in Adults: The Disorder and its Management. Orlando: Grune \& Stratton, Inc., 1984

Yoss, K.A en Darley, F.L. Developmental apraxia of speech in children with defective articulation. Journal of Speech and Hearing Re. search, 17, 399-416, 1974. 